\title{
Engaging Undergraduate Engineers in Oral Presentations: A Multimodal Approach
}

\author{
Indra Devi, S. \\ Universiti Teknikal Malaysia Melaka, Centre for Languages \& Human Development \\ Email: indradevi@utem.edu.my \\ Zaini Amir \\ Universiti Kebangsaan Malaysia, Faculty of Social Sciences \& Humanities \\ Email: zainir@ukm.edu.my \\ Pramela Krish \\ Universiti Kebangsaan Malaysia, Faculty of Social Sciences \& Humanities \\ Email: pramela@ukm.edu.my
}

\section{Doi:10.5901/mjss.2014.v5n27p1510}

\begin{abstract}
Global connectedness and digital revolution have reshaped workplace oral communication requirements. Industries today call for engineers with excellent oral communication and presentation skills. In response to this, this research attempts to move from a monomodal to a multimodal approach in teaching oral presentations for undergraduate engineers. The Learning by Design Model (LBDM) by Kalantzis and Cope (2005) is used as a framework in the teaching of oral presentation using a multimodal approach. Findings from a qualitative inquiry illustrate that the multimodal learning environment with its multiple modalities have provided a group of low proficiency undergraduates great opportunities and autonomy to mediate oral communication. Thus, this study suggests that language instructors design learning experiences that incorporate the LBDM to enhance undergraduates' achievements in oral presentations.
\end{abstract}

Keywords: undergraduate engineers; oral communication; oral presentations; multimodal approach; Learning by Design Model

\section{Introduction}

The increasing rate of competition and development in today's modern business and industry requires future engineers to be well-equipped with clear communication and oral presentation skills. To add, there are mounting evidences that highlight the centrality of oral presentation skills in the future workplaces of engineers (Kassim \& Ali, 2010; Noor Raha \& Sarjit, 2010; Luc De Grez \& Martin, 2013). Claire (2010) acknowledges oral presentations as being very critical to an engineer's career as it is viewed as one of the critical outcomes required by The Accreditation Board for Engineering and Technology. Besides, Claire adds that one would have little chance of implementing ideas successfully no matter how excellent the ideas are if these ideas are not communicated well. This exemplifies the necessity for an engineer to be well equipped with good presentation skills in order to excel in future engineering workplaces.

Accrediting bodies allow universities to decide on ways to meet the requirements but many leave the responsibility to English and media departments (American Society for Engineering Education, 2012). Although engineering faculties recognize the necessity of training students for effective communications, generally the argument is that there is too much critical technical material to be covered in the curriculum and thus oral presentations are not prioritized in engineering courses (Cochrane \& O'Donogue, 2008). Traditionally, students in engineering faculties are required to deliver oral presentations based on a list of rules provided. They are often not taught on how to present effectively and the assumption is that they would be trained in electives like public speaking courses. Contrarily, the input provided in the public speaking courses is not similar to the kind of oral presentation needed of a practicing engineer.

In the Malaysian context, Fatimah, Noor Raha and Hafizoah (2006) conducted a study on the presentations by students in engineering courses and also in the Final Year Project presentations. Their findings indicate that engineering courses emphasize more on the content rather than the use appropriate language expressions and delivery skills. Besides, when students perform oral presentations in language-based courses, most of the time due to time constraints, 
language instructors seldom provide detailed feedback on the positive and negative aspects of their presentations. To exacerbate further, literature suggests that factors like presentation of the speech as well as the communication of the message by the presenter to the audience have great influence on presentations (Otoshi \& Heffernen, 2008).

Since there have been various concerns and issues about oral presentations, there has been much debate about how oral presentations should be taught (Farina et al., 2012). Cochrane \& O'Donogue (2008) stress that oral presentations can be improved through practice and feedback. This is further supported by Nackerud and Scaletta (2008) who argue that students' engagement in the learning is highly important for a meaningful experience. In this study, the respondents are provided lots of opportunities to mediate and practice communicating orally by using multimodal resources before they indulge in oral presentations.

Employers today have unprecedented demands for graduate job-seekers who exhibit effective presenter skills (Bhattarcharya \& Sargunan, 2009). Thus, university mission statements and course learning outcomes today increasingly emphasize on students' abilities to acquire effective presentation skills. In light of this, the researchers, based on their experiences and observations as language instructors, distill their concerns on designing learning experiences that are engaging and appealing to the media-savvy, wired undergraduates of today so as to empower them with effective presentation skills.

To meet the transformations of the 20th century, a group of scholars known as The New London Group (1996, 2000) had introduced the notion of multiliteracies that is the knowledge and skills to participate actively in the globalized economies of the world. All these vigorous developments have brought about drastic expectations and implications on classroom teaching and learning. Instructors can no more overlook the digital capacities of today's new generation of media-savvy students and need to avoid being complacent with traditional teaching approaches. Rather, initiatives need to be taken to engage these wired generation with activities that connect their two worlds that is classroom learning and out-of-school literacy practices.

This study is thus conducted to fill the above-mentioned lacuna. It stresses on the move from a mono-modal approach to a multi-modal approach in teaching oral presentations and which requires the undergraduate engineers to be engaged as well as to be able to explore a variety of modes to get meaning across. The main objective of this study is to identify how the undergraduates mediate oral communication through the various multi-modal resources and activities in relation to giving oral presentations.

\section{Literature Review}

Yusoff \& Indra Devi (2012) emphasize on the additional preparation needed of undergraduates today to be work ready and to be able to handle and flourish in today's pressing economic climate and competitive labor market. At the workplace, they are most often required to present proposals for a design, product or project, progress-report of on-going investigations, final outcomes of projects, product descriptions to vendors, oral briefings and so forth. Thus, there is a call for instructors to expose, prepare and equip these undergraduates with various kinds of oral presentations, be it poster, product presentations or power-point presentations.

Whether these undergraduates are fully equipped to persevere at their future workplace is questionable. This is because, as observed by the researchers, in reality undergraduate engineers tend to shun and dread oral presentations. This statement is fuelled with evidences from related researches in this field. A research done by Park and Lee (2005) suggests that instructors should pay more attention to learner's affective domain, particularly their self-confidence and anxiety, so as to build their confidence as they communicate in English. Indra Devi and Farah Shahnaz (2008) state that undergraduates who are more confident of their communication competence have less communication apprehension and thus manage to perform better in classroom presentations. Kakepoto et al., (2012) add that several barriers like poor presentation skill, poor confidence and nervousness hinder effective oral presentation performance of engineers at the workplace.

Another issue of concern is the changing social conditions and diversity which is being pivotal in today's lifeworlds as advocated by Cope \& Kalantzis (2009). They encapsulate that old literacy is no longer adequate and needs to be replaced with a multiliteracies approach that suggests a pedagogy for active citizenship, centred on learners as agents in their own learning processes. This indeed calls for profound changes in the pedagogical practices of language instructors. Initiatives need to be taken to create learning environments that would be non-threatening but that would keep this so-called 'wired generation' engaged and immersed.

The multiliteracies pedagogy suggests the use of multimodal resources which encompass five design elements; linguistic, visual, audio, gestural, and spatial that learners must understand and be able to use (New London Group, 1996). According to Moreno (2002), the use of multiple representations is a very effective way to facilitate understanding. 
Zaini et al. (2012) define that blog in its multimodal form, in which texts and visuals meet eventually improves students' language learning. Pramela, Supyan \& Nackeeran (2011) stress that new platforms like web forums, webinars and bulletin boards in most Learner Management Systems (LMS) enhance language learning in meaningful and creative ways.

The New London Group $(1996,2000)$ had introduced four components; Situated Practice, Overt Instruction, Critical Framing and Transformed Practice to inculcate the knowledge and skills of the $21^{\text {st }}$ century learners. In Situated Practice, the instructor and learner explore the learner's existing knowledge and skills through the use of multimodal resources or situate meanings in the real world contexts. Next follows the Overt Instruction phase, where conceptualizing takes place by using a metalanguage of design. Here, the instructor facilitates learning through a scaffolding process using deductive approach or direct teaching. The instructor also bridges the learners' existing knowledge and skills to new information and knowledge through interactions with multimodal and technological resources.

Then, in the Critical Framing phase, students are able to critically analyze and interpret the social and cultural context and the political, ideological and value-centred purposes of text. The learners are involved in learning activities that encourage them to interpret, think critically as well as to analyze. Finally, in the Transformed Practice phase, the instructor facilitates the learners such that they can transform their existing knowledge or meanings and skills to new social contexts thus designing new meanings and skills. It has also been mentioned that the components do not come in a linear position but can be found in any order and could also take place simultaneously (The New London Group, 2000).

Cope and Kalantzis who were original members of The New London Group extended the component of multiliteracies pedagogy through the Learning by Design Model. They had simplified the concepts of Situated Practice, Overt Instruction, Critical Framing and Transformed Practice to core knowledge processes of experiencing, conceptualizing, analyzing and applying (Cope \& Kalantzis, 2009). According to Kalantzis and Cope (2005), the need for the construction of the Learning by Design pedagogical framework is for the purpose of translating multiliteracies and Learning by Design Theory into practice. The four ways of knowledge processes were then extended to eight subcategories (Kalantzis \& Cope, 2005) as in the following table:

Table 1. Learning by Design and Multiliteracies Equivalences (Kalantzis \& Cope, 2005)

\begin{tabular}{|l|l|}
\hline Learning by Design Knowledge Processes & Multiliteracies Curriculum Orientations \\
\hline Experiencing the Known & \\
Experiencing the New & Situated Practice \\
\hline $\begin{array}{l}\text { Conceptualizing by Naming } \\
\text { Conceptualizing with Theory }\end{array}$ & Overt Instruction \\
\hline Analyzing functions & \\
Analyzing critically & Critical Framing \\
\hline $\begin{array}{l}\text { Applying appropriately } \\
\text { Applying Creatively }\end{array}$ & Transformed Practice \\
\hline
\end{tabular}

This research uses the Learning by Design pedagogical framework by Kalantzis and Cope (2005) as a guide in planning and documenting the teaching of oral presentation skills using the multimodal approach. Multimodal resources that are used in the research include the mobile phone, You-tube videos, Power-point slides, DSLR camera and a group website (developoralcommunication.com) that incorporate print, audio, visual, gestural and spatial representations.

This study also draws on the basic tenets of Vygotsky's (1978) Socio-cultural Theory that includes the mediated mind, regulation, Zone of Proximal Development and Scaffolding. Vygotsky (1978) states that human learning and development occurs through the socialization process of learners with the world around them. According to the sociocultural theory, human learning and development is mediated through mental and semiotic tools available in the social surroundings and that language is the central tool for thought and a means of mediation.

In Vygotsky's theory, a skilled individual is capable of functioning autonomously by self-regulation while unskilled individuals learn by performing tasks under the guidance of others (other-regulation). Vygotsky (1978) Zone of Proximal Development (ZPD) aims at matching the learning with the learners' level of development. He posits on the notional gap between the learners' current developmental level and potential level of development under adult guidance or in collaboration with more capable peers. The concept of ZPD introduces another notion known as scaffolding. Vygotsky states that this concept refers to classroom learning approaches where teaching comes from an expert and his interaction with the students' environment to facilitate learning. 


\section{Research Methodology}

Taking a qualitative approach, this case study has analyzed the mediation of oral communication in a variety of multimodal activities. The Learning by Design Model by Kalantzis and Cope (2005) is used as a framework to facilitate the teaching of oral presentations using a multimodal approach. Purposive sampling is used in the selection of samples comprising fifteen 3rd-year engineering undergraduates from the Faculty of Manufacturing Engineering in a technical university in Malaysia.

The respondents are takers of a course on English for Professional Communication. They are selected based on their low achievement in the Malaysian University English Test (MUET). MUET is a standardized English proficiency test similar to IELTS and TOEFL which could be used as a yardstick to determine students' proficiency level in English (Souba \& Kee, 2011). A predictive validity study by Souba and Kee (2011) provides evidence for MUET's validity as a measure of students' English language ability.

This test assesses candidates' ability in four language skills, listening, speaking, reading and writing. The MUET scores obtained by the candidates are reported in a six-band scale with a corresponding aggregated band score for each skill. In the university where this study is conducted, undergraduates are required to obtain a minimum Band 3 , failing in which will not qualify them for graduation. All the 15 respondents of this study have obtained only a Band 1 and 2 in their past MUET test which means that they are extremely limited and limited users of the language. As for their speaking test which carries 45 marks, 14 of them had obtained less than half the scores and one of them is a borderline case.

The rationale for selecting these students is to provide them maximum exposure to oral communication via the use of a multimodal approach in the teaching of oral presentations. This study took place over a period of four weeks and it encompasses in-class and out of class activities. Using multimodal resources like video clippings, You-tube videos, Powerpoint slides, video recordings and an interactive group website (http://www.developoralcommunication.com), the researcher examined how the respondents mediate oral communication. The interactive group website (http://www.developoralcommunication.com) was designed by the principal researcher who is also the main author of this study. This website was also mainly used for the out of class activities. Every activity throughout the four instructional weeks was designed based on the Learning by Design Model by Kalantzis and Cope (2005) and the Multiliteracies Curriculum Orientation (New London Group, 1996, 2000).

The research instruments used in the study include The Oral Presentation Instructional Framework Template, video-recordings of their presentations and student written reflections on their presentations. Kalantzis and Cope (2005) created curriculum planning tools and encouraged instructors to use a template to document their teaching practices using the knowledge processes as a guide. Neville (2005) mentions that this template acts as a heuristic as it allows instructors to identify any gap or narrowness in their instructional practices. Accordingly, in this study, the researcher has also devised a template to document the instructional applications that had been employed to engage the respondents in the learning process.

Table 2. Instructional Phase for Week 1

Week 1
Activity
1a. Brainstorm on types of presentations, important aspects of presentations and how to prepare for
presentations based on video clippings.
1b. Surf the Interactive group website (http://www.developoralcommunication.com and comment or post
questions related to the various sections.
Multimodal resource: Video clippings
2a. Discuss vocabulary and terms related to verbal and non-verbal features e.g. intonation, fillers, etc.
2b.Watch You-tube videos on:
i) Presentations: Bad/Good examples
ii) Tips on giving oral presentations with Mr. Brewer
2c. Describe the physical delivery/body language
2d. Comment on the linguistic structures, visual aids and communicative ability of the presenters
2e. Ask and answer about the content of the You-tube video.
Multimodal resource: You-tube videos

The interactive website (http://www.developoralcommunication.com) comprises various sections like the Homepage, Unit Descriptions, Student Showcases, Photo \& Video Galleries, e-library, and Threaded Discussion with each having their 
well-defined purposes.

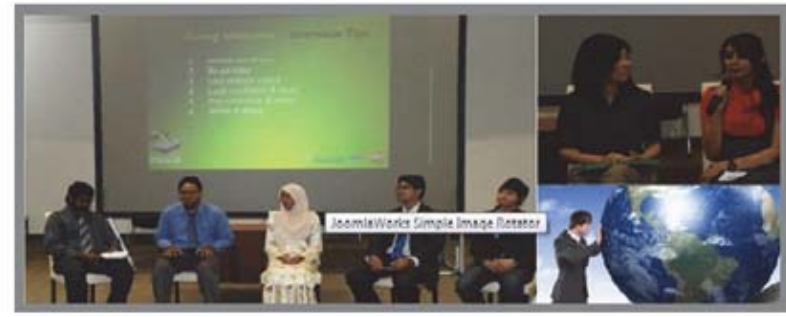

Weicome to Indra Devi's Website

Figure 1. A Clipping of the Homepage of the interactive website (http://www.developoralcommunication.com)

Oral Communication for Engineers

$$
\text { L回里 }
$$

Written by Administrator

Tuesday, 17 December $201301: 53$

2. Unit Description -

1) Oral Communication for Engineers

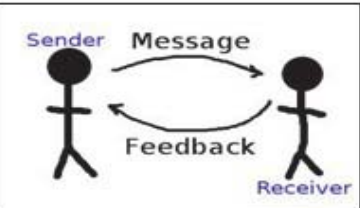

A) What is Oral Communication?

It is a form of verbal communication where message is conveyed from the sender to the receiver with the use of spoken words.

It is a two-way process and it takes the form of a speech which may be formal or informal. It encompasses various set of skills like the ability to speak coherently and persuasively, understanding of communication theory and processes, knowledge of verbal and non-verbal cues, audience analysis, listening skills and communication ethics.

Figure 2. A Clipping of the Section on Oral Communication for Engineers in the Interactive Website (http://www.developoralcommunication.com)

\begin{tabular}{|c|c|}
\hline A $\mathbf{x}$ @ask question & $\begin{array}{l}\text { 4. Saturday, } 10 \text { May } 201417: 10 \\
\text { Hanif Effendie b Kassim }\end{array}$ \\
\hline \multicolumn{2}{|c|}{ how to reduce our nervous during make oral speaking? thank you madam } \\
\hline$\Delta x \otimes$ How to reduce nervousness while speaking & $\begin{array}{l}\text { Thursday, } 08 \text { May } 2014 \text { 01:05 } \\
\text { indra devi }\end{array}$ \\
\hline \multicolumn{2}{|l|}{$\begin{array}{l}\text { 1. Ask yourself what scares you and try to overcome it } \\
\text { 2. Visualize yourself in a positive way } \\
\text { 3.Take a deep slow breath } \\
\text { 4. Speak in a cool, calm way }\end{array}$} \\
\hline$\Delta \mathbf{x} \odot$ Verbal cues and non-verbal cues & $\begin{array}{l}\text { 3. Wednesday, } 07 \text { May } 201401: 40 \\
\text { indra devi }\end{array}$ \\
\hline \multicolumn{2}{|c|}{$\begin{array}{l}\text { Dear Hafiz, } \\
\text { Gd question that you've raised. In oral communication verbal cues include the use of spoken words and non-verbal cues include gestures } \\
\text { eg. nod of the head, pitch,eye-contact etc. }\end{array}$} \\
\hline A $\odot$ My Question & $\begin{array}{l}\text { 2. Tuesday, } 06 \text { May } 2014 \text { 00:48 } \\
\text { Mohamad Nor Hafiz b Che Ab Hamid }\end{array}$ \\
\hline \multicolumn{2}{|c|}{ What does "verbal cues" mean? \& How is it difference from non-verbal cues? } \\
\hline$\Delta \mathbf{x} \bigcirc$ You may ask questions & $\begin{array}{l}\text { 1. Monday, } 05 \text { May } 2014 \text { 17:19 } \\
\text { indra devi }\end{array}$ \\
\hline
\end{tabular}

Figure 3. Sample of Students' Postings and Instructor's Response in the Interactive Website (http://www.developoralcommunication.com) 
Table 3. Instructional Phase for Week 2

\begin{tabular}{l} 
Week 2 \\
Activity \\
1. Discuss design elements on power-point slides in You-tube "How to give a killer presentation" \\
2. Comment on the design elements, e.g. \\
i) linguistic- modality to connect message and target audience, written (explanation, instruction, grammar etc.) \\
ii) visual- color to create mood, different fonts, animations, clipart, drawings text effects, e.g. bolding, underlining, \\
capitalization, layout and spacing, punctuation, spelling, etc. indenting, lines and borders to delineate important details. \\
iii) audio- music to evoke particular emotions, moods, feelings and responses (classical, popular, instrumental, vocal) \\
sound effect (found or custom recorded, recorded speech). \\
iv) Spatial- slide sequence, custom animation of slide elements, slide timing, interactive features like hyperlinks. \\
Multimodal resource: Power-point slides \\
3. Present on the following topics (A representative from each group) \\
Comment on the positive and negative elements in the presentation (other members) \\
i) Marriage \\
ii) Birthdays \\
iii) Festivals \\
Multimodal Resource - \\
4. Discuss on the visuals and non-verbal gestures in the images of personalities in the webpage on Oral Presentation in \\
group website: developoralcommunication.com \\
Multimodal resource: Interactive group website (http://www.developoralcommunication.com) \\
\hline
\end{tabular}

\begin{tabular}{|c|c|}
\hline \multicolumn{2}{|l|}{ Comments (4) } \\
\hline a) Oral Presentation & $\begin{array}{l}\text { 4. Wednesday, } 07 \text { May } 2014 \text { 14:18 } \\
\text { indra devi }\end{array}$ \\
\hline \multicolumn{2}{|c|}{$\begin{array}{l}\text { Ros, a pleasnt, clear, loud voice, good posture, assurance in speech, tone, intonation, being knowledgeable about the topic and your } \\
\text { enthusiasm in handling the presentation will mirror a positive attitude to the audience }\end{array}$} \\
\hline$\underline{x} \otimes$ Eye Contact & $\begin{array}{l}\text { 3. Wednesday, } 07 \text { May } 2014 \text { 14:12 } \\
\text { indra devi }\end{array}$ \\
\hline \multicolumn{2}{|c|}{$\begin{array}{l}\text { My dear Syahirah, when you are presenting formally its immaterial if its a guy or a lady whom you are making eye contact. You can look at the } \\
\text { person and then gradually look at all the the other members of the audience.Direct eye contact will make an immediate impact on the listener } \\
\text { and will enable you to know whether the listener is receiving or accepting your message. }\end{array}$} \\
\hline$\underline{x}$ @eye contact & $\begin{array}{l}\text { 2. Tuesday, } 06 \text { May } 2014 \text { 00:27 } \\
\text { Nur Syahirah bt.Shafie }\end{array}$ \\
\hline \multicolumn{2}{|c|}{ As a female, is it okay if I don't show eye contact when looking at audience when are males? } \\
\hline $1 \times$ Ooral presentation & $\begin{array}{l}\text { 1. Monday, } 05 \text { May } 2014 \text { 22:43 } \\
\text { Roslina bt. Razali }\end{array}$ \\
\hline \multicolumn{2}{|c|}{ Madam, in an oral presentation, how can I show positive attitude to the audience? } \\
\hline
\end{tabular}

Figure 4. Question and Answer Section in the Unit on Oral Presentation for Engineers in the Interactive Website (http://www.developoralcommunication.com)

Table 4. Instructional Phase for Week 3
Week 3
Activity
1. Discuss and list down in groups about the important elements in a presentation.
2. Discuss on the elements that can be included as criteria in the Assessment form.
3. Explain about the relevance of each criteria scaffolded by instructor.
Multimodal resource: Laptop \& LCD
4. Appoint leader for every group.
5. Assign task for every member.
6. Submit project topic which is based on their technical report.
Multimodal resource: Laptop and LCD
7. Threaded online discussion monitored by instructor in http://www.developoralcommunication.com
Topic of threaded discussion:
i. How can I improve my oral presentation?
ii. Am I prepared for oral communication at the workplace? 
Figure 5. Threaded Discussion on 'How to Improve my Oral Presentation' in Interactive Website (http://www.developoralcommunication.com)

Table 5. Instructional Phase for Week 4

Week 4
1. Presentation of technical report by groups and instructor awards marks.
2. Video-record the presentations using smart phone (A representative does this).
3. Write reflections based on peers' presentations while the presentation is ongoing (focus on elements like verbal
proficiency, body language, quality of content, strong and weak points and suggestions for improvements)..
4. Transfer the video recording into a laptop for the purpose of class viewing later.
Multimodal resource: Smartphone, laptop, poster based on technical report
5. Class viewing of the recordings, self-reflection of presentation based on the recordings and discussion based on both
self-reflection and peer-reflection.
6. Students provide opinions on the viewing of the video recorded presentations.
7. Instructor discusses on the marks and takes students' justifications into consideration.
8a. Demonstration by class representative on how to create digital video using DSLR camera and 'Sony Vegas' software
8b. Demonstration by class representative on how to upload the created digital video into
http://www.developoralcommunication.com website.
8c. Q \& A session
Out of Class Activity:
Digital Video creation
Upload video at http://www.developoralcommunication.com website.

Following are sample clippings from the students' video recordings. 

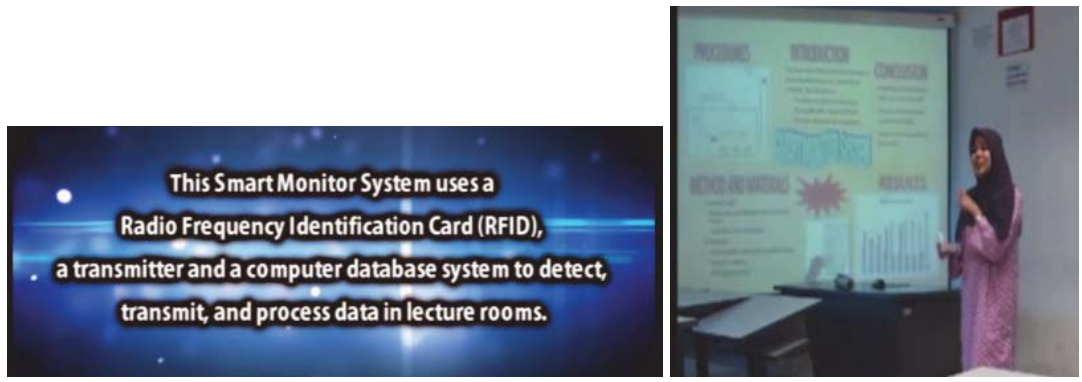

Figure 6. Clippings from Students' Video Recordings of a Technical Report Presentation

\section{Findings}

The data were compiled and analyzed based on the objectives of the study. Using the instructional template that had been devised, the researchers were able to identify how the students mediated oral communication. In the Situated Practice phase, the respondents were required to list out positive and negative aspects in oral presentatins based on video clippings. They were also required to surf the http://www.developoralcommunication.com website and have access, share or comment on the various sections. In this activity students were immersed in the topic and this has helped them to make connections between prior and new knowledge and they started discussing and giving opinions in a nonthreatening environment.

In the second activity in week 1, they were involved in the Overt Instruction phase where they were required to identify the verbal and non-verbal features based on presentations in You-tube videos. Here, they were able to conceptualize by naming new vocabularies like credibility, speech-fillers, body language, accent, etc. Thus, they were able to communicate using several related vocabulary during the activity. In week 2 , they were required to comment on design elements on power-point slides. In this Overt Instruction phase they were able to conceptualize by naming design elements like linguistics, visual, audio, spatial, etc. This understanding of the metalanguage was useful to them in the facilitation of relevant expressions during their discussion.

In the next activity in week 2, they were indulged in the Critical Framing phase, which required them to analyze the positive and negative elements in a two-minute presentation performed by a representative from their group. This activity has provoked them to think critically in the process of assessing their friends and thus promoted an interactive discussion. When they were asked to evaluate on the visuals and non-verbal gestures of personalities in the interactive group website (http://www.developoralcommunication.com), they were positioned in a decision-making process and were compelled to comment and exchange ideas.

In week 3, they were again involved in the Overt Instruction phase which enabled them to firstly, conceptualize by theorizing when they started working on the list of criteria for the oral presentation assessment form. In this activity they were involved in discussing and making generalizations about each given criteria which include aspects like content and organization, language aspect which includes command of structures, vocabulary, pronunciation, stress and intonation patterns, physical delivery, body language as well as visual aids and creativity. Then, they began to conceptualize by naming when they were required to plan, classify and assign roles for each member of the group. Besides discussing they also mediated negotiation skills in this activity. This is followed by the Transformed Practice Phase where they were involved in a threaded online discussion on the interactive website (http://www.developoralcommunication.com). In this threaded online discussion, they responded directly to one another on the assigned topics.

In week 4, they were again involved in a transformed practice phase when they had to present a technical report individually by groups which was video-recorded using smart phone by a representative from each group. This activity provided them an opportunity to show their awareness of all the rudiments of oral presentations that they had studied in class. Besides, this encouraged them to apply their knowledge creatively and at the same time they tried their best to present information such that it is aesthetically attractive.

The enactment of the Critical Framing phase was again evident in week four when the students were required to analyze their peer presentations critically as well as write out their reflections. Then, the video-recording was transferred into a laptop for the purpose of class viewing. During the viewing of the recordings, the undergraduates discussed on their reflections of their peers' presentations. They were also able to reflect on their own presentation from the viewpoint of an audience. Then, they were required to provide opinions on the activity. This enabled them to present their views and critiques. Next, the instructor reveals on the marks awarded to every presenter followed by a discussion which takes 
students' justifications into consideration. The final activity is a demonstration by the class representative on how to create digital video and upload in the interactive website. This activity enabled the students to analyze logical connections in coming up with the digital video creation and thus steered them to be involved in the question and answer session. Table 6 below provides a thematic description of how the respondents mediated oral communication based on the LBDM throughout the four instructional weeks.

Table 6: Thematic Analysis of the Mediation of Oral Communication Based on the LBDM in Weeks 1-4

\begin{tabular}{|l|l|}
\hline $\begin{array}{l}\text { Learning by Design } \\
\text { Knowledge Processes }\end{array}$ & Mediation of Oral Communication by the respondents \\
\hline Experiencing the known & $\begin{array}{l}\text { List out orally the positive and negative aspects in oral presentations based on video } \\
\text { clippings. }\end{array}$ \\
\hline Experiencing the new & $\begin{array}{l}\text { Share, comment or post questions in http://www.developoralcommunication.com . } \\
\text { Discuss and give opinions based on video clippings of oral presentations. }\end{array}$ \\
\hline Conceptualizing by naming & $\begin{array}{l}\text { Communicate using vocabulary related to verbal and non-verbal features in oral } \\
\text { presentations on You-Tube videos. } \\
\text { Comment on design elements in powerpoint slides. } \\
\text { Discuss and negotiate roles of every member in the digital video creation project. }\end{array}$ \\
\hline Conceptualizing with theory & $\begin{array}{l}\text { Discuss and generalize on elements that can be included as criteria in the oral presentation } \\
\text { assessment form. }\end{array}$ \\
\hline Analyzing functions & Demonstrate on how to create digital video using DSLR camera and 'Sony Vegas' software. \\
\hline Analyzing critically & $\begin{array}{l}\text { Comment and discuss on the positive and negative elements in oral presentations. } \\
\text { Comment and exchange ideas based on the evaluation of visuals used in oral } \\
\text { presentations and non-verbal gestures of personalities. }\end{array}$ \\
\hline Applying appropriately & Respond to one another's ideas in threaded online discussion. \\
\hline Applying creatively & $\begin{array}{l}\text { Present a technical report individually by groups. } \\
\text { Discuss and reflect on the video-recorded presentations. }\end{array}$ \\
\hline
\end{tabular}

\section{Discussion}

Exploring the undergraduate students' oral communication while preparing for oral presentations reveals how students mediate oral communication with their peers, instructor and with the multimodal resources as well as the manner in which they combine multiple modes to make meaning. In the various activities, students were given lots of opportunities to discuss and to present, but their language errors were not corrected by the instructor. In fact, they were encouraged to ask more questions and seek clarifications so as to promote them to practise using the language as well as identify themselves whatever mistakes they make in their speech. This concurs with past researches e.g. by Swain \& Lapkin (1998) who stress on the need for language learners to be provided opportunities to be active participants who speak and produce the language besides listening to it.

Besides the undergraduates' exposure to the important elements in presentations, like verbal and non-verbal communication etc. during their involvement in the multimodal activities throughout the four weeks, has enabled them to see the relationship between all these elements in performing well in an oral presentation. McNulty \& Lazarevic (2012) too reverberate that activities of this kind increase students' motivation and enables students to be actively involved in the learning process. This is evident through the students' participation in the activities as well as in their final product, that is their digital videos which were uploaded into http://www.developoralcommunication.com .

This study also exemplifies the features of Vygotsky's theory which stresses on the role of mediatory tools to facilitate learning. The use of various mediatory tools like the interactive website, You-tube videos, smart-phones for video-recording, DSLR cameras etc. leave an impact on the social environment as advocated by Vygotsky as it affects the way learners express thoughts. This study also promotes learners to acquire knowledge in the Zone of Proximal Development (ZPD). Reflections from students have indicated that peer-group discussions have assisted them to learn new knowledge e.g. like how to create digital videos and also more opportunities to communicate in English. The activities designed by the researcher have provided the students genuine practice and with scaffolding by the instructor and peer-group they had been able to work collaboratively as groups in discussing and presenting.

The findings of this study confirms that the incorporation of the LBDM enables language instructors to design learning experiences that would provide ample opportunities for undergraduates to mediate oral communication before they indulge in oral presentations. The various multimodal activities which include a combination of knowledge processes 
like experiencing, conceptualizing, analyzing and applying enable the undergraduates to be responsive and engaged in the learning. This kind of learning environment is in sync with their digital lifestyles. This concurs with past studies, example by Neville (2010) who advocates that the Learning by Design Pedagogical Framework facilitates quality multimodal literacy teaching and learning, thus enhancing students' achievement in curriculum.

\section{Conclusion}

Involving the undergraduate engineers in various multimodal activities has enabled the infusion of Social Constructivist pedagogical strategies as well as promote the undergraduates' engagement in oral presentations. These kinds of activities have indeed added an experiential flavor to the classroom instruction. Literature in related studies that describe students' experience in creating videos, too point out on the importance of such exposure to students (Greene \& Crespi, 2012).

The findings of this study have also illuminated how the multimodal approaches to teaching oral presentations allow learners to adapt to new ways of learning. It has also provided a setting for them to be engaged and to practice using the English language by moving from solely traditional print-based materials to innovative and versatile use of multimodal resources. The kaleidoscope of multimodal activities have provided the students with a variety of opportunities to learn as well as to discuss, comment, exchange ideas, answer questions, negotiate, reflect, demonstrate and present their content in multiple representations that encompass texts, video, audio and images. In conclusion, the multimodal activities had stimulated them to interact vigorously with their peers and have facilitated the practice of oral presentations in an authentic and meaningful way.

\section{References}

American Society for Engineering Education. (2012). PRISM Dec. 2012.

Bhattacharyya, E. \& Sargunan, R.A. (2009). The technical oral presentation skills and attributes in Engineering education: Stakeholder perceptions and university preparation in a Malaysian context. 20th Australasian Association for Engineering Education Conference. University of Adelaide, 6-9 December 2009.

Claire, L.M.C. (2010). A comedy of errors: Teaching oral presentation skills using a spectacularly bad presentation. ASEE Southeast Section Conference 2010.

Cochrane, T.A. \& O'Donogue, M. (2008). Improving oral presentation skills of engineering students with the Virtual-i Presenter (ViP)program. In Proc. the 2008 Australasian Association for Engineering Education (AAEE) Conference.

Cope, B. \& Kalantzis, M. (2009). Multiliteracies: New literacies, new learning. Pedagogies: An International Journal, 4, 164-195. doi: 10, 1080/15544800903076044

Farina, N.T., Suzana, A.B., Fauziah, S.A.H., Aznizam, A., Noornisa, I. \& Cochrane, T.A. (2012). Implementing a virtual presentation program in ESL classrooms. In International Journal of e-Education, e-Business, e-management and e-Learning, Vol. 2, №. 3, pp. 218-222.

Fatimah, A., Noor Raha, M.R. \& Hafizoah, K. (2006). Oral presentation skills for engineering students: Industry's perspectives. 4th $^{\text {Asia }}$ TEFL International Conference, 18-20 August 2006.

Greene, H. \& Crespi, C. (2012). The value of student created videos in the college classroom- An exploratory study in marketing and accounting. International Journal of Arts \& Sciences, 5(1), pp. 273-283. USA.

Indra Devi, S., \& Farah, S.F. (2008). Oral communication apprehension and communicative competence among electrical engineering undergraduates in UTeM. Journal of Human Capital Development. Vol. 1. No. 1 (June-December 2008).

Kakepoto, I., Habil, H., Omar, N.A.M. \& Said, H. (2012). New trends in modern industry and oral presentation barriers of engineers of Pakistan. Research on Humanities and Social Sciences Vol. 2, No. 9.

Kalantzis, M., Cope, B. \& The Learning by Design Project Group. (2005). Learning by Design. Melbourne, VIC: Victorian Schools Innovation Commission.

Kassim, H., \& Ali, F. (2010). English communicative events and skills needed at the workplace: feedback from the industry. English for Specific Purposes; Vol 29, pp 168-182.

Luc, D.G. \& Martin, V. (2013). Student response system and how to make engineering students learn oral presentation skills. International Journal of Engineering Education Vol. 29, No. 4, pp. 940-947.

McNulty, A. \& Lazarevic, B. (2012). Best practices in using video technology to promote second language acquisition. In Teaching English with Technology, 12(3), pp. 49-61.

Moreno, R. (2002). Who learns best with multiple representations? Cognitive theory implications for individual differences in multimedia learning. Paper presented at EDMEDIA 2002 Conference: Denver, Colorado, USA.

Nackerud, S. \& Scaletta, K. (2008). Blogging in the academy. New Directions for Students' Services, vol. 124, pp. 71-87.

Neville, M. (2006). Teaching multimodal literacy using the learning by design approach to pedagogy: Case studies from selected Queensland schools. Masters Thesis, Royal Melbourne Institute of Technology University, Australia.

Neville, M. (2010). Meaning making using new media: Learning by design case studies. In E-Learning and Digital Media, Vol. 7, No. 3, 
pp. 237-247.

Noor Raha, M.R. \& Sarjit, K. (2010). Engineering lecturers' perceptions of students' technical presentations in English: Negotiating best practices. RCEE \& RHEd 2010. Kuching, Sarawak. 7-9 June 2010.

Otoshi, J. \& Heffernen, N. (2008). Factors predicting effective oral presentations in EFL classrooms. In Asian EFL Journal, Vol. 10, Issue 1, March 2008

Park, H. \& Lee, A.R. (2005). L2 Learners' anxiety, self-confidence and oral performance. Kunsan National University \& Concordia University.

Pramela, K., Supyan, H., \& Nackeeran, S. (2011). Language learning and language acquisition in online forums. The Southeast Asian Journal of English Language Studies Vol. 17(2), pp. 91-100.

Souba, R. \& Kee, M.C. (2011). The Malaysian University English Test (MUET) and its use for placement purposes: A predictive validity study. Electronic Journal of Foreign Language Teaching, Vol. 8, No. 2, pp. 234-245. National University of Singapore.

Swain, Merrill \& Sharon Lapkin 1998. Interaction and second language learning: Two adolescent French immersion students working together. In: Modern Language Journal 82(3). P. 320-337.

The New London Group. (1996). A pedagogy of multiliteracies: Designing social futures. Harvard Education Review, Vol. 66, No. 1 Spring, pp 60-92.

The New London Group. (2000). A pedagogy of multiliteracies: Designing social futures. In Cope, B. and Kalantzis, M. (eds.) Multiliteracies: Literacy learning and the design of social futures. London: Routledge.

Vygotsky, L. (1978). Mind and society. Cambridge: Haward University Press.

Yusoff, M. \& Indra Devi, S. (2012). Honing employability skills: Graduate-Industry experience sharing. Proceedings of ICERI 2012 Conference, 19-21 Nov. 2012, Madrid, Spain. pp. 2732-2738.

Zaini, A., Hazirah, A., Saadiyah, D. \& Kemboja, I. (2012). Gender differences in the language use of Malaysian Teen Bloggers, GEMA Online ${ }^{\mathrm{TM}}$ Journal of Language Studies, Vol. 12, (1), 105-124. 